\title{
Penambahan Kulit Buah Naga Merah (Hylocereus undatus) dan Kunyit (Curcuma domestica rhizomes) sebagai Pigment Feed Additive terhadap Kualitas Telur Puyuh (Cortunix cortunix japonica)
}

\author{
Addition of Red Dragon Fruit (Hylocereus undatus) Peel and Turmeric (Curcuma domestica \\ rhizomes) as Pigment Feed Additive on Quail Egg Quality (Cortunix cortunix japonica)
}

\author{
M. Hilmi, A. U. Prastujati, dan A. Khusnah \\ Program Studi Teknologi Pengolahan Hasil Ternak Politeknik Negeri Banyuwangi \\ Jl. Raya Jember Km. 13, Labanasem, Kabat, Banyuwangi \\ E-mail : mustofahilmi@poliwangi.ac.id
}

\begin{abstract}
The aims of this study was to determine the effect of red dragon fruit (Hylocereus undatus) peel and turmeric (Curcuma domestica rhizomes) on quail egg quality. The experiment was a completely randomized design (CDR) with six treatments and three replications and eight birds of each replication. The treatment diets were T0 : Control diet, (T1) T0 + 6\% peel red dragon fruit (Hylocereus undatus), (T2) T0 + 3\% peel red dragon fruit (Hylocereus undatus), (T3) T0 + 6\% turmeric (Curcuma domestica rhizomes), (T4) T0 + 3\% turmeric (Curcuma domestica rhizomes), (T5) T0 + 3\% peel red dragon fruit (Hylocereus undatus) $+3 \%$ turmeric (Curcuma domestica rhizomes). The results showed that the addition of turmeric $6 \%$ were significantly $(\mathrm{P}<0.01)$ in increasing egg weight, yolk weight, yolk color score compared with other treatments. While the combination treatment of 3\% and 3\% of turmeric powder dragon fruit peels is highly significant $(\mathrm{P}<0.01)$ in improving the color of egg yolk and lower the haught unit. The conclusion of this experiment was that the addition of turmeric $6 \%$ able to improve egg weight, egg yolk, egg yolk color score and combined treatment of 3\% and 3\% of turmeric powder dragon fruit can enhance the color of egg yolk and lower the haught unit.
\end{abstract}

Key words: dragon fruit, egg, pigment, tumeric, quail.

\begin{abstract}
ABSTRAK
Tujuan dari penelitian ini adalah untuk mengetahu efektivitas kulit buah naga merah dan kunyit sebagai pigments feed additiv ke dalam pakan dalam meningkatkan kualitas telur puyuh. Penelitian ini menggunakan rancangan acak lengkap (RAL) dengan enam perlakuan dan tiga ulangan, masing-masing menggunakan 8 puyuh. Perlakuan yang diberikan pada saat in vivo (lapang) sebagai berikut : (T0) ransum basal, (T1) T0 + 3\% kulit buah naga merah, (T2) $\mathrm{T} 0+6 \%$ kulit buah naga merah, (T3) T0 + 3\% kulit buah naga kuning, (T4) T0 + 6\% kulit buah naga kuning, (T5) $\mathrm{T} 0+3 \%$ kulit buah naga merah $+3 \%$ kulit buah naga kuning. Hasil penelitiaan menunjukkan bahwa penambahan kunyit $6 \%$ sangat nyata $(\mathrm{P}<0.01)$ meningkatkan berat telur, kuning telur, skor warna kuning telur dibandingkan dengan perlakuan lainnya. Perlakuan kombinasi 3\% kunyit dan 3\% tepung kulit buah naga sangat nyata $(\mathrm{P}<0.01)$ meningkatkan warna kuning telur dan menurunkan haught unit. Kesimpulan yang dapat diambil adalah penambahan kunyit 6\% mampu meningkatkan berat telur, kuning telur, skor warna kuning telur dan kombinasi perlakuan 3\% kunyit dan 3\% tepung buah naga dapat meningkatkan warna kuning telur dan menurunkan haught unit.
\end{abstract}

Kata kunci : buah naga, telur, pigmen, kunyit, puyuh.

\section{PENDAHULUAN}

Burung puyuh merupakan salah satu jenis unggas yang harus dikembangkan dan ditingkatkan produksi karena sangat potensial dan efisien serta cepat menghasilkan kebutuhan protein hewani seperti telur dan daging untuk masyarakat. Hal sesuai dengan data meningkatnya populasi burung puyuh dari 2011 sampai 2015 sebesar 7.356.64812.903.759 (BPS, 2015), ini membuktikan bahwa burung puyuh merupakan komoditas yang memiliki potensi di bidang perunggasan dan banyak diminati antara masyarakat 
(Ditjennak, 2016). Keuntungan bisnis puyuh pada usia enam minggu sudah mulai berproduksi, tidak memerlukan modal yang besar, mudah pemeliharaan serta juga dapat dipelihara pada areal yang terbatas. Untuk menghasilkan kualitas telur yang baik banyak peternak menggunakan antibiotik sintetis dan pewarna sintetis yang dicampur ke dalam pakan. Warna kuning telur adalah faktor yang sangat penting dalam penjualan telur kualitas dan penjualan di masyarakat (SantosBocanegra et al., 2004).

Penggunaan antibiotik atau antimikrobial sebagai bahan aditif dalam pakan ternak telah berlangsung lebih dari 40 tahun. Senyawa antibiotik sintetis tersebut digunakan sebagai growth promoter dalam jumlah yang relatif kecil namun dapat meningkatkan efisiensi pakan (feed efficiency) dan reproduksi ternak sehingga dengan penggunaan bahan aditif tersebut peternakan dapat memperoleh keuntungan lebih banyak. Menurut Saeid dan Al-Nasry (2010) bahwa masalah keamanan pangan asal hewan dimasyarakat meliputi kontaminasi mikroba patogen dan residu antibiotik dalam daging dan telur sebagai efek samping antibiotik dalam pakan yang berperan sebagai Antibiotic Growth Promoters (AGPS).

Langkah-langkah harus diambil untuk mengatasi masalah ini adalah dengan memanfaatkan kulit buah naga (Handayani dan Rahmawati 2012; Rosa et al. 2013) dan kunyit (Curcuma domestica rimpang) (Abdeldaiem, 2014). Kulit buah naga merupakan sumber mineral, nutrisi, antioksidan dan pigmen seperti $\beta$-carotin, licopen, anthocyanin (Santoso 2009; Wahyuni 2011; Handayani dan Rahmawati 2012; Rosa et al., 2013). Menurut Rosa et al. (2013) menyatakan bahwa penambahan tepung kulit buah naga $4 \%$ ternyata mempengaruhi konsumsi pakan, persentase produksi telur harian dan berat telur puyuh. Sementara penambahan tepung kunyit (Curcuma domestica rimpang) dari $0-7 \%$ bisa meningkatkan kualitas telur puyuh (Amo et al., 2013).

\section{MATERI DAN METODE}

Kulit buah naga merah (hylocereus undatus) diperoleh di Politeknik Negeri Banyuwangi di Kabat, Banyuwangi, Jawa timur dan kunyit (Kunir/Curcuma domestica) diperoleh dari para petani di Glenmore, Banyuwangi, Jawa timur. Kulit buah naga merah (Hylocereus undatus) dan kunyit (Kunir/Curcuma domestica) yang dikeringkan dalam oven dengan suhu $60^{\circ} \mathrm{C}$ selama 24 jam kemudian digiling sampai berbentuk tepung (mash).

Feeding trial pada penelitian ini menggunakan 180 ekor puyuh petelur ( \pm umur 6 minggu). Penelitian ini mengunakan rancangan acak lengkap menggunakan 6 perlakuan dan 3 ulangan masing-masing ulangan terdiri dari 10 ekor puyuh pada kandang dengan ukuran dengan ukuran $60 \mathrm{~cm}$ x $40 \mathrm{~cm}$ x $20 \mathrm{~cm}$, yang masing - masing berisi 10 ekor puyuh dilengkapi tempat pakan dan tempat air minum. Perlakuan terdiri T0 : kontrol, (T1) T0 $+6 \%$ tepung kulit buah naga (Hylocereus undatus), (T2) T0 $+3 \%$ tepung kulit buah naga (Hylocereus undatus), (T3) T0 $+6 \%$ kunyit (Curcuma domestica rhizomes), (T4) T0 + 3\% kunyit (Curcuma domestica rhizomes), (T5) T0 $+3 \%$ tepung kulit buah naga (Hylocereus undatus) $+3 \%$ kunyit 
(Curcuma domestica rhizomes). Ransum petelur, yaitu protein $18 \%$ dan energi penelitian disusun berdasarkan Leeson dan metabolis $2950 \mathrm{kkal} / \mathrm{kg}$.

Summers (2009), untuk kebutuhan puyuh fase

Tabel 1. Komposisi dan Kandungan Nutrisi Ransum (Hilmi, 2015)

\begin{tabular}{lc}
\hline Komposisi & Kandungan Nutrisi (\%) \\
\hline Jagung & 58,20 \\
Bungkil Kedelai & 21,50 \\
Tepung Ikan & 5,00 \\
Bekatul & 1,50 \\
Corn gluten meal (CGM) & 2,80 \\
Minyak Sawit & 2,63 \\
Di-calcium phosphate (DCP) & 0,90 \\
CaCO3 & 6,71 \\
NaCl & 0,30 \\
Premix & 0,30 \\
DL-Methionine & 0,16 \\
\hline Total & 100 \\
\hline Nutrient content ${ }^{1}$ & \\
ME (kcal/kg) & 2950,25 \\
Crude protein (\%) & 18,08 \\
Crude fat $(\%)$ & 5,19 \\
Crude fiber (\%) & 2,40 \\
Methionine (\%) & 0,53 \\
Lysine (\%) & 1,11 \\
Methionine + Cysine (\%) & 0,85 \\
Ca (\%) & 3,10 \\
P available(\%) & 0,53 \\
Na (\%) & 0,19 \\
\hline Note: ${ }^{1}$ Formulasi ransum berdasarkan rekomendasi kebutuhan nutrisi oleh Leeson \\
$\quad$ and Summers (2009)
\end{tabular}

Puyuh dipelihara selama 10 minggu dibagi menjadi 3 tahapan, yaitu satu minggu untuk adaptasi lingkungan, satu minggu untuk adaptasi pakan perlakuan, dan delapan minggu untuk makan percobaan. Pakan dan air minum diberikan ad libitum. Variabel diamati adalah kualitas fisik telur. Kualitas fisik telur diamati di minggu ke-5, ke-6, ke-7, dan ke-8 dengan mengambil secara acak 3 butir telur dari masing-masing ulangan perlakuan.

\section{Analisa Statistik}

Data yang diperoleh dianalisis dengan menggunakan analysis of variance (ANOVA).
Jika terdapat perbedaan yang nyata antara perlakuan maka dilanjutkan dengan uji Duncan multiple range (Mattjik dan Sumertajaya, 2006).

\section{HASIL DAN PEMBAHASAN}

Perlakuan penambahan tepung kunyit 6\% (T4) dalam pakan pada penelitian ini berpengaruh sangat nyata $(\mathrm{P}<0,01)$ terhadap berat telur. Hasil penelitian berbeda dengan penelitian oleh Amo et al. (2013) yang menemukan kosentrasi penambahan serbuk kunyit lebih tinggi yang dicampur ke dalam 
pakan dapat meningkatkan besar ukuran dan berat kuning telurnya. Hal ini dipengaruhi oleh jumlah protein yang diperoleh melalui kunyit atau pakan sehingga berat telur meningkat.

Meningkatnya berat telur dipengaruhi oleh kandungan protein yang terkandung dalam bahan pakan dan bagian kunyit. Hal ini sejalan dengan penelitian Rahmat dan Kusnadi (2008) menunjukkan bahwa tepung kunyit berpengaruh signifikan terhadap kandungan protein, karena pada kunyit mengandung senyawa aktif yang dikategorikan sebagai antioksidan yang mampu mengatasi/ mengurangi stres oksidatif (Kumar et al., 2006), sehingga terganggunya sintesis protein dapat ditekan/diatasi sehingga kandungan protein lebih tinggi dari pada kontrol dan berdampak peningkatan bobot telur. Selain itu, zat aktif yang terkandung dalam kunyit memiliki gugus hidroksil yang mudah teroksidasi, sehingga dapat mudah untuk menyumbangkan kelompok hidrogen dan elektron untuk radikal bebas, akibatnya muncul radikal bebas yang mengganggu sintesis protein dikurangi/ditekan (Priyadarsini, 2014).

Hasil penelitian ini berat telur puyuh sesuai dengan standar yang direkomendasikan oleh Tserveni-Goussi dan Fortomaris (2011) yang berkisar antara 6-16g. Faktor yang mempengaruhi berat telur adalah konsumsi protein (Darmawan et al., 2013; Tuleun dan Adenkola 2013), hormon (Latifa 2007) dan umur puyuh (Tserveni-Goussi dan Fortomaris 2011). Lebih lanjut (Leeson and Summers (2009) mengemukakan bahwa protein atau asam amino merupakan nutrisi yang berperan penting dalam menggontrol bobot telur.
Perlakuan tidak berbeda nyata $(\mathrm{P}>$ $0,05)$ terhadap berat putih telur. Bobot ratarata berat putih telur sebesar 9,90 g. Hal ini menunjukkan bahwa penggunaan tepung kulit buah naga dan kunyit tidak mempengaruhi berat putih telur. Berat putih telur biasanya dipengaruhi oleh berat telur, umur, genetik (Zita et al., 2009) dan hormon (Latifa, 2007). Berat rata-rata putih telur dalam penelitian ini lebih rendah dibandingkan dengan hasil penelitian Tserveni-Goussi dan Fortomaris (2011) dengan menggunakan pakan pakan basal, yaitu 7,80 g.

Peningkatan bobot kuning telur dari perlakuan yang dikombinasikan kunyit dan pakan diduga berperan sebagai karatinoid. Kandungan karatinoid dan kurkumin mampu meningkatkan penyerapan protein untuk proses pembentukan kuning telur (Leeson dan Summers (2009). Selanjutnya Windisch et al. (2008) disarankan kurkumin dan jenis karatinoid yang mampu meningkatkan daya cerna protein dan lemak dalam tubuh berasal dari pakan. Rajkumar et al. (2009) dan Darmawan et al. (2013) menyatakan bahwa ukuran telur lebih terkait dengan ukuran kuning telur dibandingkan dengan albumen, terlepas dari fakta bahwa albumin masih penting untuk menentukan ukuran telur. Menurut Zita et al. (2013) dan Dunn (2011) bobot kuning telur dipengaruhi oleh genotipe dan umur dan kadar kolesterol. Perlakuan tidak berbeda nyata $(\mathrm{P}>0,05)$ terhadap berat kulit telur dan ketebalan kulit telur. Berat ratarata dan ketebalan kulit telur: 1,03 sampai 1,16 $\mathrm{g}$ dan 0,16 sampai 0,22 $\mathrm{mm}$ dan masih dalam kisaran normal. Menurut Keshavarz (2003) peningkatan ukuran telur atau berat telur 
menghasilkan pengurangan ketebalan persentase bobot telur).

cangkang telur dan berat telur (sebagai

Tabel 3. Rataan kualitas fisik telur puyuh umur 9-14 minggu

\begin{tabular}{lllcccc}
\hline \multirow{2}{*}{ Peubah } & \multicolumn{5}{c}{ Perlakuan } \\
\cline { 2 - 7 } & \multicolumn{1}{c}{$\mathrm{T} 0$} & \multicolumn{1}{c}{$\mathrm{T} 1$} & $\mathrm{~T} 2$ & $\mathrm{~T} 3$ & $\mathrm{~T} 4$ & $\mathrm{~T} 5$ \\
\hline $\begin{array}{l}\text { Egg weight }(\mathrm{g}) \\
\text { Albumen }\end{array}$ & $10.09 \pm 0.29^{\mathrm{B}}$ & $10.17 \pm 0.25^{\mathrm{B}}$ & $9.90 \pm 0.63^{\mathrm{B}}$ & $9.77 \pm 0.21^{\mathrm{B}}$ & $12.32 \pm 0.26^{\mathrm{A}}$ & $12.30 \pm 0.15^{\mathrm{A}}$ \\
$\begin{array}{l}\text { weight (g) } \\
\text { Berat kuning }\end{array}$ & $5.22 \pm 0.16$ & $5.22 \pm 0.12$ & $5.19 \pm 0.24$ & $5.41 \pm 0.15$ & $5.46 \pm 0.18$ & $5.18 \pm 0.2$ \\
telur (g) & $3.71 \pm 0.49^{\mathrm{B}}$ & $3.66 \pm 0.43^{\mathrm{B}}$ & $3.42 \pm 0.39^{\mathrm{B}}$ & $3.23 \pm 0.14^{\mathrm{B}}$ & $5.81 \pm 0.29^{\mathrm{A}}$ & $6.10 \pm 0.09^{\mathrm{A}}$ \\
$\begin{array}{l}\text { Yolk weight }(\mathrm{g}) \\
\text { Eggshell }\end{array}$ & $1.16 \pm 0.07$ & $1.10 \pm 0.09$ & $1.13 \pm 0.02$ & $1.03 \pm 0.02$ & $1.05 \pm 0.07$ & $1.03 \pm 0.02$ \\
thickness (mm) & $0.17 \pm 0.01$ & $0.19 \pm 0.05$ & $0.17 \pm 0.06$ & $0.16 \pm 0.06$ & $0.20 \pm 0.04$ & $0.22 \pm 0.04$ \\
$\begin{array}{l}\text { Haugh unit } \\
\text { Yolk score }\end{array}$ & $91.12 \pm 1.10^{\mathrm{CD}}$ & $93.19 \pm 1.10^{\mathrm{AB}}$ & $92.56 \pm 0.49^{\mathrm{BC}}$ & $94.49 \pm 0.86^{\mathrm{A}}$ & $89.69 \pm 0.79^{\mathrm{D}}$ & $89.69 \pm 0.99^{\mathrm{D}}$ \\
\hline Keterangan: Angka-angka yang diikuti oleh huruf yang sama pada baris yang sama berarti berbeda tidak nyata pada
\end{tabular}

Keterangan: Angka-angka yang diikuti oleh huruf yang sama pada baris yang sama berarti berbeda tidak nyata pada taraf $1 \%$

Kualitas kerabang dan bentuk telur naga bubuk buah 3\% (T1) nyata dapat dapat dipengaruhi oleh umur dan mineral. meningkatkan biovabilitas nutrisi satu satunya Kandungan nutrisi yang terkandung dalam asam amino, glukosa dan beta karotin (Khan et pakan seperti kalsium, magnesium dan fosfor al., 2006; Ahmad et al., 2012). Menurut sebagai konteinen anorganik (Hincke et al., Nugraha et al. (2013) bahwa peningkatan 2011; Darmawan et al., 2013). Selanjutnya, penyerapan asam amino dapat menopang Leeson dan Summers (2009) dan Karoui et al. ovomucin dan lesitin sehingga meningkatkan (2009) menyatakan bahwa nutrisi mineral yang berkontribusi terhadap ketebalan dan kekuatan kulit telur, yaitu kalsium, magnesium, karbonat, fosfor, vitamin D3 dan nutrisi organik lainnya termasuk protein. Selanjutnya, menurut komposisi telur standar Mine and D'Silva (2008) dari semua jenis unggas mulai dari $32 \%-35 \%$, putih telur $52 \%-58 \%$, dan cangkang telur $9 \%-14 \%$.

Penambahan tepung kunyit 3\% (T3) berpengaruh sangat nyata $(\mathrm{P}<0,01)$ dalam meningkatkan nilai haugh unit dibandingkan dengan T0, T3 dan T4 namun tidak berbeda nyata $(\mathrm{P}>0,05)$ dengan perlakuan $\mathrm{T} 2$. Ratarata nilai nilai haugh unit selama penelitian 8 minggu berkisar antara 89,69-94,49. Penambahan tepung kunyit 3\% (T3) dan buah kualitas telur, asam amino digunakan untuk meningkatkan viskositas putih telur dan unit Haugh unit akan meningkat.

Selanjutnya, Honkatukia et al. (2013) menjelaskan bahwa ovomucin mampu mengendalikan kualitas albumin protein dan membantu proses viskositas albumin telur. Nugraha et al. (2013) menjelaskan bahwa kandungan ovomucin dalam putih telur mempengaruhi nilai haugh unit, putih telur lebih tinggi, maka nilai haugh unit didapat lebih tinggi. Dalam hasil penelitian ini menunjukkan bahwa telur termasuk di kelas AA. Menurut US Department of Agriculture (USDA, 2011), nilai haugh unit di atas 72 dikategorikan kualitas telur AA, 60-72 Telur kualitas A, haugh unit telur kualitas 31-60 B, 
dan nilai unit Haugh kurang dari 31 kualitas telur C.

Kombinasi 3\% tepung kunyit dan tepung buah naga 3\% (T5) berpengaruh sangat nyata $(\mathrm{P}<0,01)$ dalam meningkatkan skor telur dibandingkan perlakuan lainnya kecuali T4, sedangkan perlakuan T1, T2 dan T3 secara signifikan $(\mathrm{P}<0,01)$ lebih tinggi dari $\mathrm{T} 0$. Penambahan perlakuan ternyata bisa menambahkan karoten yang terkandung dalam pakan. Karatinoid dan kurkumin adalah zat yang dapat mempengaruhi warna pigmen dan kuning telur memiliki fungsi yang sama dengan xantopil (Nolan et al., 2016). Hammershoj et al., (2010) menyatakan bahwa warna kuning telur dipengaruhi oleh konsumsi zeaxanthin, lutein, alpha-carotine, beta-karotin dan karatinoidas serta curcumin yang ditemukan dalam kunyit.

\section{KESIMPULAN}

Penambahan tepung kunyit 6\% mampu meningkatkan bobot telur, kuning telur, nilai warna kuning telur dan kombinasi perlakuan $3 \%$ tepung kulit buah naga dan 3\% tepung kunyit dapat meningkatkan warna kuning telur dan menurunkan haught unit.

\section{DAFTAR PUSTAKA}

Abdeldaiem, M. H. 2014. Use of yellow pigment extracted from turmeric (Curcuma longa) rhizomes powder as natural food preservative. American Journal of Food Science and Technology. 2 (1): 36-47.

Ahmad, N., H. Fazal, B. H. Abbasi, S. Farooq, M. Ali, and M. A. Khan. 2012. Biological role of Piper nigrum L. (Black pepper): A review. Asian Pacific Journal of Tropical Biomedicine 2 (3,
Supplement) : S1945-S1953. doi: http://dx.doi.org/10.1016/S2221$\underline{1691(12) 60524-3}$

Amo, M., J. L. P. Saerang, and M. Najoan. 2013. Pengaruh penambahan tepung kunyit dalam ransum terhadap kualitas telur puyuh. Zootek. 33:48-57.

[PBS] Badan Pusat Statistik. 2015. Populasi ternak yang dipelihara oleh rumah tangga usaha peternakan sesuai jenis ternak yang diusahakan menurut wilayah dan jenis ternak. www.bps.go.id. Jakarta.

Darmawan, A., K. G. Wiryawan, and S. Sumiati. 2013. Egg production and quality of magelang duck fed diets containing different ratio of omega 3 : omega 6 and organic Zn. Media Peternakan. 36(3):197-202. doi: 10.5398/medpet.2013.36.3.197

[Ditjennak] Direktoral Jenderal Peternakan dan Kesehatan Hewan. 2016. Populasi peternakan menurut provinsi. Jakarta.

Dunn, I. 2011. 11 - Poultry breeding for egg quality: traditional and modern genetic approaches. In Y. Nys, M. Bain \& F. V. Immerseel (Eds.), improving the safety and quality of eggs and egg products (pp. 245-260): Woodhead Publishing.

Handayani, P. A. dan A. Rahmawati. 2012. Pemanfaatan kulit buah naga (dragon fruit) sebagai pewarna alami makanan pengganti pewarna sintetis. Jurnal Bahan Alam Terbarukan. 1(2) : 19-24.

Hammershoj, M., U. Kidmose, and S. Steenfeldt. 2010. Deposition of carotenoids in egg yolk by short-term supplement of coloured carrot (Daucus carota) varieties as forage material for egg laying hens. J Sci Food Agric. 90 (7):1163-1171. doi:10.1002/jsfa.3937.

Hincke, M., J. Gautron, A. B. RodriguezNavarro, and M. D. McKee. 2011. The eggshell: structure and protective 
function. Improving the safety and quality of eggs and egg products: egg chemistry, production and consumption (pp. 151-182).

Karoui, R., B. De Ketelaere, B. Kemps, F. Bamelis, K. Mertens, and J. De Baerdemaeker. 2009. Chapter 15 - eggs and egg products. Infrared spectroscopy for food quality analysis and control: Di dalam: D-W Sun, editor San Diego, Academic Press. 399-414.

Keshavarz, K. 2003. Effects of reducing dietary protein, methionine, choline, folic acid, and vitamin B12 during the late stages of the egg production cycle on performance and eggshell quality. Poult. Sci. 82 (9):1407-1414

Khan, I. A., Z. M. Mirza, A. Kumar, V. Verma, and G. N. Qazi. 2006. Piperine, a phytochemical potentiator of ciprofloxacin against Staphylococcus aureus. Antimicrob Agents Chemother. $50 \quad$ (2): 810-812. doi: 10.1128/AAC.50.2.810-812.2006

Kumar, G. S., H. Nayaka, S. M. Dharmesh, and P.V. Salimath. 2006. Free and bound phenolic antioxidants in Amla (Emblica officinalis) and turmeric (Curcuma longa). Journal of Food Composition. 19 (5): 446-452.

Hilmi, M., Sumiati. and D. Astutik. 2015. Egg production and physical quality in Cortunix cortunix japonica fed diet containing piperine as phytogenic feed additive. Media Peternakan. 38 (3): 150155 .

Honkatukia, M., M. Tuiskula-Haavisto, J. Arango, J. Tabell, M. Schmutz, R. Preisinger, and J. Vilkki. 2013. QTL mapping of egg albumen quality in egg layers. Genet. Sel. Evol. 45 (1): 31-31. http://dx.doi.org/10.1186/1297-9686-4531
Latifa, R. 2007. The increasing of afkir duck's egg quality with pregnant mare's serum gonadotropin (PMSG) hormones. Jurnal Protein. 14 (1) : 21-30.

Leeson, S. and J. D. Summers. 2009. Commercial poultry nutrition. Ed: 3rd. England, Nottingham University Press. p.198.205.

Rahmat, A. and E. Kusnandi. 2008. Pengaruh penambahan tepung kunyit (Curcuma domestica Val. ) dalam ransum yang diberi minyak jelantah terhadap performan ayam broiler. Jurnal Ilmu Ternak. 8 (1): 25 - 30

Mattjik, A. A dan M. Sumertajaya. 2006. Perancangan percobaan dan aplikasi SAS dan Minitab. Jilid I. Edisi ke 2. Bogor (ID): IPB Press.

Mine, Y. and I. D'Silva. 2008. Bioactive components in egg white, in egg bioscience and biotechnology (ed Y. Mine), John Wiley \& Sons, Inc., Hoboken, NJ, USA. doi: 10.1002/9780470181249.ch4

Nolan, J. M., K. A. Meagher, A. N. Howard, R. Moran, D. I. Thurnham, and S. Beatty. 2016. Lutein, zeaxanthin and mesozeaxanthin content of eggs laid by hens supplemented with free and esterified xanthophylls. Journal of Nutritional Science. $5 . \quad$ e1. http://doi.org/10.1017/jns.2015.35

Nugraha, B. A., K. Widayaka, and N. Iriyanti. 2013. Penggunaan berbagai jenis probiotik dalam ransum terhadap haugh unit dan volume telur ayam arab. Jurnal Ilmiah Peternakan. 1(2): 606 - 612.

Priyadarsini, K. I. 2014. The Chemistry of Curcumin: From Extraction to Therapeutic Agent. Molecules. 19 (12): 20091-20112; doi:10.3390/molecules191220091 
Rosa, R.A., M. A. Malik, I. G. Prakoso, R. W. Djati, and Y. Purnamawati. 2013. Suplemen pakan berbasis limbah kulit buah naga (Hylocereus undatus) guna menghasilkan telur puyuh yang kaya vitamin A dan rendah kolesterol. Institut Pertanian Bogor, Bogor.

Saeid, J. and A. Al-Nasry. 2010. Effect of dietary coriander seeds supplementation on growth performance carcass traits and some blood parameters of broiler chickens. IJPS. 9 (9):867-870.

Santos-Bocanegra, E., X. Ospina-Osorio, E. Oviedo-Rondon. 2004. Evaluation of xanthophylls extracted from Tagetes erectus (Marigold flower) and Capsicum Sp.(Red pepper paprika) as a pigment for egg-yolks compare with Synthetic pigments. International Journal of Poultry Science. 3(11):685-689.

Santoso, V. S. 2009. Efek Penggunaan Ekstrak Kulit Buah Naga Merah dan Ubi Jalar Ungu terhadap Karakteristik Sensoris dan Perubahan Sifat Fisikokimiawi Marshmallow selama Penyimpanan. Doctoral dissertation. Prodi Teknologi Pangan Unika Soegijapranata.

Rajkumar, U., R. P. Sharma, K. S. Rajaravindra, M. Niranjan, B. L. N. Reddy, T. K. Bhattacharya, and R. N. Chatterjee. 2009. Effect of Genotype and Age on Egg Quality Traits in Naked Neck Chicken under Tropical Climate from India. International Journal of Poultry Science. 8(12):1151-1155.doi: 10.3923/ijps.2009.1151.1155.

Tserveni-Goussi, A. and P. Fortomaris. 2011. Production and quality of quail, pheasant, goose and turkey eggs for uses other than human consumption. In Y. Nys, M. Bain \& F. V. Immerseel (Eds.), Improving the safety and quality of eggs and egg products (pp. 509-537): Woodhead Publishing.

Tuleun, C. and A. Adenkola. 2013. Performance and erythrocyte osmotic membrane stability oflaying japanese quails (Coturnix coturnix japonica) fed varying dietary protein levels in a hothumid tropics. Agric. Biol. J. N. Am. 4 (1): 6-13.

[USDA]. United State Departement of Agriculture National. 2011. Nutrient database for standard reference. United States of America.

Wahyuni, R. 2011. Pemanfaatan kulit buah naga supermerah (Hylicereus costaricensis) sebagai sumber antioksidan dan pewarna alami pada pembuatan jelly. Jurnal Teknologi Pangan. 2(1) : 68-85.

Windisch, W., K. Schedle, C. Plitzner, and A. Kroismayr. 2008. Use of phytogenic products as feed additives for swine and poultry. J Anim Sci. 86 (14 Suppl), E140-148. doi: 10.2527/jas.2007-0459

Zita, L., E. Tůmová, and L. Štolc. 2009. Effects of genotype, age and their interaction on egg quality in brown-egg laying hens. Acta Veterinaria Brno. 78 (1): 85-91.

Zita, L., Z. Ledvinka, L. Klesalová, Z. Ledvinka, L. Klesalová, and T. Japanese. 2013. The effect of the age of japanese quails on certain egg quality traits and their relationships. Vet. Arhiv. 83 (2): 223- 232. 